\title{
BMJ Open A systematic review of qualitative research on the contributory factors leading to medicine-related problems from the perspectives of adult patients with cardiovascular diseases and diabetes mellitus
}

\author{
A Al Hamid, ${ }^{1}$ M Ghaleb, ${ }^{1}$ H Aljadhey, ${ }^{2}$ Z Aslanpour ${ }^{1}$
}

To cite: Al Hamid A, Ghaleb M, Aljadhey $\mathrm{H}$, et al. A systematic review of qualitative research on the contributory factors leading to medicine-related problems from the perspectives of adult patients with cardiovascular diseases and diabetes mellitus. BMJ Open 2014;4: e005992. doi:10.1136/ bmjopen-2014-005992

- Prepublication history for this paper is available online. To view these files please visit the journal online (http://dx.doi.org/10.1136/ bmjopen-2014-005992).

Received 30 June 2014 Revised 27 August 2014 Accepted 28 August 2014

\section{CrossMark}

${ }^{1}$ Department of Pharmacy, School of Life and Medical Sciences, University of Hertfordshire, Hatfield, Hertfordshire, UK

${ }^{2}$ Medication Safety Research Chair, Clinical Pharmacy Department, College of Pharmacy, King Saud University, Riyadh, Saudi Arabia

Correspondence to Dr A M Al Hamid; a.alhamid@herts.ac.uk

\section{ABSTRACT}

Objectives: To synthesise contributing factors leading to medicine-related problems (MRPs) in adult patients with cardiovascular diseases and/or diabetes mellitus from their perspectives.

Design: A systematic literature review of qualitative studies regarding the contributory factors leading to MRPs, medication errors and non-adherence, followed by a thematic synthesis of the studies.

Data sources: We screened Pubmed, EMBASE, ISI Web of Knowledge, Psyclnfo, International Pharmaceutical Abstract and PsycExtra for qualitative studies (interviews, focus groups and questionnaires of a qualitative nature).

Review methods: Thematic synthesis was achieved by coding and developing themes from the findings of qualitative studies.

Results: The synthesis yielded 21 studies that satisfied the inclusion and exclusion criteria. Three themes emerged that involved contributing factors to MRPs: patient-related factors including socioeconomic factors (beliefs, feeling victimised, history of the condition, lack of finance, lack of motivation and low self-esteem) and lifestyle factors (diet, lack of exercise/time to see the doctor, obesity, smoking and stress), medicine-related factors (belief in natural remedies, fear of medicine, lack of belief in medicines, lack of knowledge, nonadherence and polypharmacy) and condition-related factors (lack of knowledge/understanding, fear of condition and its complications, and lack of control). Conclusions: MRPs represent a major health threat, especially among adult patients with cardiovascular diseases and/or diabetes mellitus. The patients' perspectives uncovered hidden factors that could cause and/or contribute to MRPs in these groups of patients.

\section{INTRODUCTION}

Medicine-related problems (MRPs) emerged as a concept in the early 1990s as "the

\section{Strengths and limitations of this study}

- To the best of our knowledge, it is the first systematic review conducted on qualitative research regarding the contributory factors leading to medicine-related problems from the perspectives of adult patients with cardiovascular diseases and diabetes mellitus.

- The study undertook a comprehensive systematic review with a thematic synthesis approach.

- Despite using studies from 12 countries, the analytical themes developed from the review comprised a high level of conceptual thinking that could be applied across different studies.

- The review was restricted to the experiences of patients from 12 countries, which could limit the generalisability of the findings.

- The qualitative studies $(n=21)$ in the literature were limited, so further qualitative studies are needed to assess the contributory factors leading to medicine-related problems.

detrimental experience regarding drug therapy, which potentially or actually causes an interference with its desired outcome."1 MRPs affect healthcare and economic situations and contribute to a tremendous increase in morbidity, mortality and healthcare expenditure worldwide. ${ }^{2-4}$

MRPs represent a major issue, particularly in chronic conditions such as cardiovascular diseases (CVDs) and diabetes mellitus (DM) ${ }^{5}$ The aforementioned conditions are expected to be the major source of morbidity by $2020 .{ }^{6}{ }^{7}$ In addition, these two conditions are interrelated; it has been documented that $\mathrm{DM}$ is a key factor that leads to CVDs, as people with diabetes are three to four times more likely to have a CVD. ${ }^{8}{ }^{9}$ Consequently, the combination of CVDs and DM, which can 
result in multiple complications, represents a major concern for healthcare professionals.

More specifically, patients with CVDs and/or DM are more susceptible to MRPs due to long-term use of medicines and the inevitable polypharmacy. ${ }^{7} 1011$ However, many additional factors that contribute to MRPs in patients with CVDs and/or DM have gone underreported.

Studies in the literature, which investigated risk factors contributing to MRPs in patients with CVDs/DM, were mainly quantitative; only a few studies were qualitative. Quantitative studies investigating risk factors contributing to MRPs involved either direct observations or were made retrospectively using data extracted from medical records. ${ }^{12-15}$ However, most of the studies reported old age and polypharmacy extensively; few studies reported gender, depression, education, cohabitation and immobilisations. ${ }^{16}$ Nonetheless, qualitative studies investigating contributory risk factors leading to MRPs have been rather limited.

Therefore, this review aims to explore and evaluate contributory factors leading to MRPs among adult patients with CVDs and/or DM from their perspectives.

\section{METHODS}

We searched the PubMed, EMBASE, ISI Web of Knowledge, PsycInfo, International Pharmaceutical Abstract and PsycExtra databases for entries between January 1990 and March 2014. The search strategy evaluated articles obtained predominantly through databases. Additional articles were retrieved through the bibliography lists of published reviews, where applicable.

The search strategy combined established methodological terms for qualitative research (qualitative research, qualitative studies, nursing methodological research, narrative analysis) and the following terms: Medicine (drug/medication) related problems, medicine (drug/medication) use, diabetes mellitus, cardiovascular diseases, patients' perspectives, patients' beliefs, patients' attitudes, patients' views, patients' opinions, patients' knowledge, patients' behaviours and contributory factors. In addition, Medical Subject Headings (MeSH) relating to MRPs, CVDs/DM, risk factors and patients' perspectives were explored.

\section{Study selection}

We included studies that utilised phone interviews, face-to-face interviews, focus groups and open-ended questionnaires published in peer-reviewed journals.

The inclusion criteria involved studies focusing on patients' perspectives on the use of medicines and MRPs and were conducted on adult patients with CVDs and/ or DM.

On the other hand, the exclusion criteria flagged studies that were quantitative in nature, studies with closed-ended questionnaires and studies focusing on conditions other than CVD/DM.

Initially, one reviewer (AA) conducted the search and screened titles. At this stage, studies with irrelevant titles were excluded. Next, the abstracts of the remaining studies were evaluated independently for inclusion by two reviewers (MG and ZA). Any disagreements that were encountered were resolved via a discussion. No language limits were applied. However, the search results only generated English studies. Figure 1 demonstrates the details of the data extraction process.

\section{Data synthesis and analysis}

In order to extract data from articles, we adopted the systematic review approach for qualitative research by Dixon-Woods et al. ${ }^{17}$ This allowed the emergence of

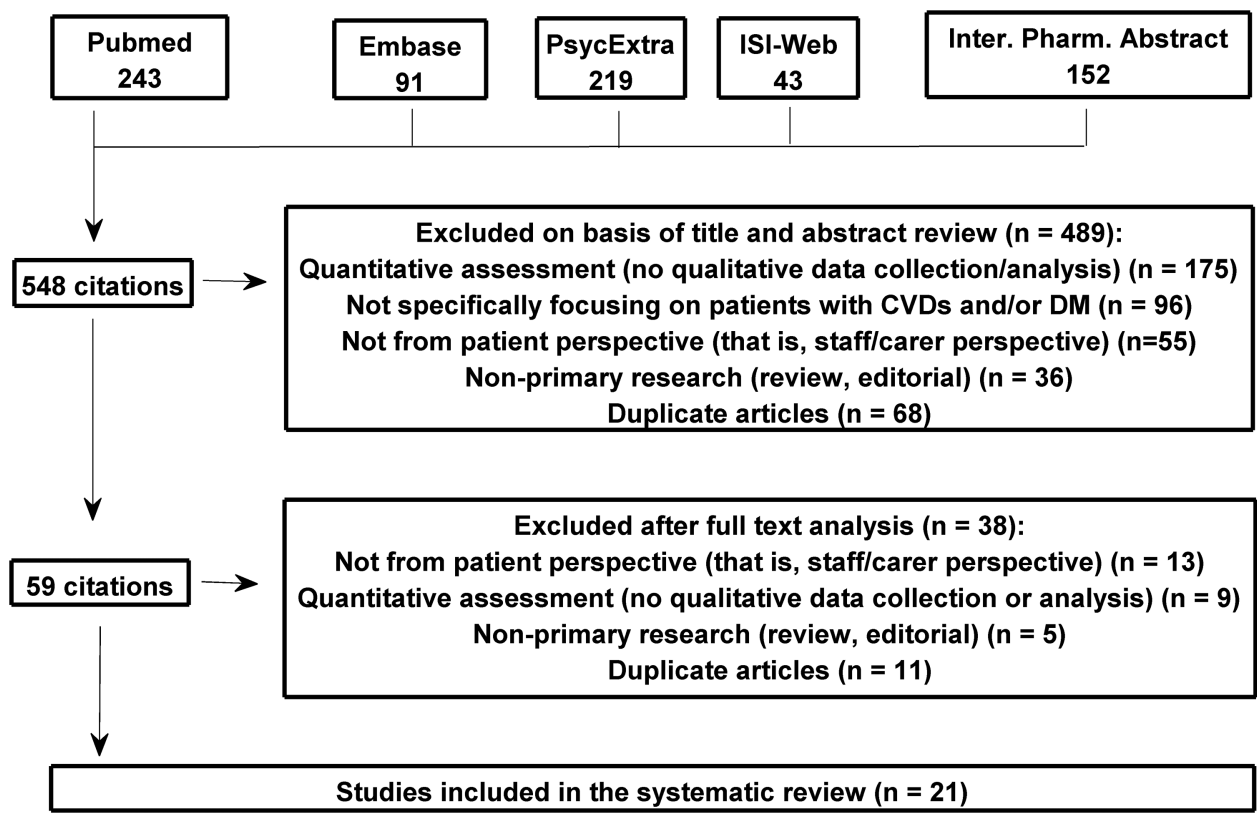

Figure 1 Data extraction and study selection process. CVD, cardiovascular diseases, DM, diabetes mellitus. 
broad concepts. Then, data was synthesised by utilising the thematic analysis approach, ${ }^{18}$ which enables extraction of concepts and hypotheses from multiple qualitative studies.

Based on the extracted results, we developed textual summaries and tables. From the textual summaries and tables, we identified emerging themes which described the meaning and content of the included studies. We then inspected similarities and differences across the textual summaries in order to avoid contradiction and reduce the developed number of themes. Subsequently, we agreed on the final list of themes through discussion and consensus.

Finally, we coded the full list of papers for the presence or absence of themes. The codes were tabulated afterwards by country in order to inspect similarities and differences across countries.

Since our approach was qualitative, the presence of a theme in more than one paper did not indicate its importance in the studied population. ${ }^{19}$ However, a theme appearing in more than one paper did denote to a degree its validity. Thus, the number of studies within a specific theme was reported in this review.

\section{Quality of synthesis assessment}

The quality of papers was assessed using the checklist developed by Dixon-Woods et $a l^{17}$ This assessment was based mainly on clarity, consideration of ethical issues, and transferability of the sample data and analysis across different settings. Furthermore, the critical appraisal skills programme criteria ${ }^{20}$ were used to rank the papers based on 10 questions that fulfilled the clarity, methods and results of the studies. Consequently, studies were grouped into low (one star: 0-3 points), medium (two stars: 4-7 points) and high quality (three stars: 8-10 points). Low-quality studies were not excluded, but caution was taken when interpreting their results.

\section{RESULTS}

A total of 21 studies (including 836 participants) from 12 countries met the inclusion criteria (table 1) and were conducted in the following countries: Australia, ${ }^{21}$ Brazil, ${ }^{22}$ Cameroon, ${ }^{23}$ Canada, ${ }^{24}$ Croatia, ${ }^{25}$ Ireland, ${ }^{26}$ Malaysia, ${ }^{27} 28$ South Africa, ${ }^{29}$ Spain, ${ }^{30}$ Taiwan, ${ }^{31}$ the $\mathrm{UK}^{7}{ }^{32-37}$ and the USA. ${ }^{38-40}$ The majority of the studies investigated type $2 \mathrm{DM}(\mathrm{n}=15)$; fewer studies investigated CVDs. Thus, only two studies investigated hypertension (HTN), one investigated heart failure and one studied CVDs in general. The remaining two studies investigated $\mathrm{DM} / \mathrm{HTN}$ and $\mathrm{DM} / \mathrm{HTN} /$ stroke, respectively. Eight studies used focus groups, 12 used interviews and one study used a mixture of these methods. The review covered areas related to patients, conditions and medicines.

\section{Narrative synthesis}

The main findings of the review showed that contributory factors to MRPs involved three themes: patientrelated (socioeconomic and lifestyle), medicine-related and condition-related factors. Table 2 lists the studies that reported or discussed each theme.

\section{Patient-related factors}

\section{Socioeconomic-related factors}

Patients from six countries reported socioeconomic factors leading to MRPs in DM and CVDs, including: beliefs, family history of the condition, poor finances, relationships with healthcare professionals (lack of communication and not enough education), inadequate knowledge and low self-esteem (table 2).

Beliefs regarding CVDs/DM were reported as a problem in three studies from the UK. ${ }^{32} 3436$ Patients perceived that DM was given by God and higher powers had control over their condition. One patient reported:

'God has given me this disease of sugar. Whatever happens, it happens because God wants it to happen.'

Moreover, a family history of DM was reported in three studies from the $\mathrm{UK}^{3436}$ and the USA. ${ }^{38}$

In addition, poor finances were reported by patients in four studies from Ireland, ${ }^{26}$ South Africa, ${ }^{29}$ Croatia $^{25}$ and the USA. ${ }^{39}$ A lack of necessary finances prevents patients from buying the appropriate food (for their diet) ${ }^{29}$ and from going to doctors. ${ }^{26}$

Consequently, the financial situation implicated the relationship of the patients with the healthcare professionals. Patients have reported that they were not getting value for their money from healthcare providers. ${ }^{26}$ For instance, one patient reported:

I don't mind paying when I'm sick, but it's very expensive to pay the GP when I'm only getting a check-up with the nurse.

Thus, the patients felt victimised by healthcare professionals $^{25} \quad 2629$ and reported a lack of communication with healthcare professionals. ${ }^{18}$ They described doctors as either too busy to see them ${ }^{26} 27$ or not giving enough information about diagnosis and medicines. ${ }^{32} 33 \quad 37$ Other patients reported having been belittled by doctors. $^{25}$ In another study, patients accounted for the lack of communication with healthcare professionals due to language barriers. ${ }^{33}$

Subsequently, patients reported a lack of knowledge as a major cause for type $2 \mathrm{DM}^{25}$ This situation led to the lack of motivation about their disease and affected the intake of medicines. Patients asserted the need for further education and training about their condition.

A lack of knowledge resulted in patients' low-self esteem because of their condition. ${ }^{25} 40$ Hence, patients felt unaccepted socially, less comfortable with their colleagues and less worthy, from being diabetic. ${ }^{25} 40$ 
Table 1 Characteristics of the included studies

\begin{tabular}{|c|c|c|c|c|c|c|c|c|}
\hline Study & Country & Study type & $\begin{array}{l}\text { Patients' } \\
\text { diagnosis }\end{array}$ & $\begin{array}{l}\text { Method of } \\
\text { analysis }\end{array}$ & Study population & Study settings & Study aims & $\begin{array}{l}\text { Study } \\
\text { quality }\end{array}$ \\
\hline Al-Qazaz et $a f^{7}$ & Malaysia & $\begin{array}{l}\text { Semistructured } \\
\text { interviews }\end{array}$ & Type 2 DM & $\begin{array}{l}\text { Content } \\
\text { analysis }\end{array}$ & $\begin{array}{l}12 \text { diabetic patients, with } \\
\text { at least } 1 \text { year of } \\
\text { diabetes and a } \\
\text { prescription of oral } \\
\text { hypoglycaemic }\end{array}$ & USM Health Clinic & $\begin{array}{l}\text { To explore diabetic } \\
\text { patients' experience and } \\
\text { knowledge about } \\
\text { diabetes and its } \\
\text { medication and to } \\
\text { understand the factors } \\
\text { contributing to } \\
\text { medication adherence in } \\
\text { Malaysian population }\end{array}$ & ** \\
\hline Brown et $a^{\beta 2}$ & UK & $\begin{array}{l}\text { One-to-one } \\
\text { interviews }\end{array}$ & Type 2 DM & $\begin{array}{l}\text { Thematic } \\
\text { analysis }\end{array}$ & $\begin{array}{l}17 \text { African-Caribbean } \\
\text { diabetes patients aged } \\
\text { above } 18 \text { years; } 13 \text { first } \\
\text { generation immigrants } \\
\text { and four } \\
\text { second-generation } \\
\text { immigrants }\end{array}$ & Inner city Nottingham & $\begin{array}{l}\text { To gain an } \\
\text { understanding of how } \\
\text { health beliefs influence } \\
\text { the way African- } \\
\text { Caribbean people with } \\
\text { diabetes manage their } \\
\text { illness }\end{array}$ & *** \\
\hline Choudhury et $a^{\beta 3}$ & UK & Structured interview & Type 2 DM & $\begin{array}{l}\text { Thematic } \\
\text { analysis }\end{array}$ & $\begin{array}{l}14 \text { invited Bangladeshi } \\
\text { individuals, ( } 4 \text { males and } \\
10 \text { females), aged } \\
\text { between } 26 \text { to } 67 \text { years, } \\
\text { with type } 2 \text { DM (had it } \\
\text { from six months- } \\
27 \text { years) and were } \\
\text { recruited either in } \\
\text { Swansea or Birmingham. } \\
\text { Interviews were made in } \\
\text { either English or in } \\
\text { Sylheti as the researcher } \\
\text { was bilingual }\end{array}$ & $\begin{array}{l}\text { Participants from local } \\
\text { communities in } \\
\text { Swansea and } \\
\text { Birmingham were invited } \\
\text { for the interview }\end{array}$ & $\begin{array}{l}\text { To examine the } \\
\text { understanding and } \\
\text { beliefs of people with } \\
\text { diabetes from the } \\
\text { Bangladeshi community } \\
\text { living in the UK }\end{array}$ & ** \\
\hline Coronado et $a \beta^{\beta 8}$ & USA & Focus groups & Type 2 DM & $\begin{array}{l}\text { Matrix } \\
\text { analysis by } \\
\text { Morgan } \\
\text { and } \\
\text { Krueger }\end{array}$ & $\begin{array}{l}42 \text { individuals ( } 14 \text { men } \\
\text { and } 28 \text { women) in six } \\
\text { focus groups, who had } \\
\text { diabetes, had a family } \\
\text { history of diabetes, or } \\
\text { knew someone who had } \\
\text { diabetes }\end{array}$ & $\begin{array}{l}\text { Fred Hutchinson Cancer } \\
\text { Research Center's } \\
\text { project office in } \\
\text { Sunnyside, Yakima } \\
\text { Village and Skagit } \\
\text { Valley Community } \\
\text { College and at the } \\
\text { Catholic Church in } \\
\text { Burlington }\end{array}$ & $\begin{array}{l}\text { To investigate the } \\
\text { perceptions about the } \\
\text { causes of and } \\
\text { treatments for type } 2 \mathrm{DM}\end{array}$ & * \\
\hline
\end{tabular}




\begin{tabular}{|c|c|c|c|c|c|c|c|c|}
\hline Study & Country & Study type & $\begin{array}{l}\text { Patients' } \\
\text { diagnosis }\end{array}$ & $\begin{array}{l}\text { Method of } \\
\text { analysis }\end{array}$ & Study population & Study settings & Study aims & $\begin{array}{l}\text { Study } \\
\text { quality }\end{array}$ \\
\hline Cottrell et $a R^{21}$ & Australia & Structured interview & $\mathrm{HF}$ & $\begin{array}{l}\text { Repertory } \\
\text { grid } \\
\text { technique }\end{array}$ & $\begin{array}{l}92 \text { patients (older than } \\
18 \text { years) with heart } \\
\text { failure }\end{array}$ & $\begin{array}{l}\text { Heart Failure Service } \\
\text { outpatient clinic, Royal } \\
\text { Brisbane and Women's } \\
\text { Hospital in Brisbane, } \\
\text { Australia }\end{array}$ & $\begin{array}{l}\text { To elicit individuals' } \\
\text { beliefs about their heart } \\
\text { failure treatment and to } \\
\text { investigate whether } \\
\text { generated constructs } \\
\text { were different between } \\
\text { adherent and } \\
\text { non-adherent patients }\end{array}$ & * \\
\hline Gascon et $\left.a\right|^{\beta 0}$ & Spain & $\begin{array}{l}\text { Focus groups with } \\
\text { open ended } \\
\text { questions }\end{array}$ & HTN & $\begin{array}{l}\text { Thematic } \\
\text { analysis }\end{array}$ & $\begin{array}{l}\text { Seven focus groups of } \\
44 \text { patients ( } 24 \text { men and } \\
20 \text { women), diagnosed } \\
\text { with hypertension, } \\
\text { between the ages of } 18 \\
\text { and } 80 \text { years, being } \\
\text { treated with } \\
\text { antihypertensives for } \\
3 \text { months, being } \\
\text { non-compliant and } \\
\text { having sufficiently good } \\
\text { physical and mental } \\
\text { health to participate }\end{array}$ & $\begin{array}{l}\text { Two primary healthcare } \\
\text { centres }\end{array}$ & $\begin{array}{l}\text { To identify factors } \\
\text { related to } \\
\text { non-compliance with the } \\
\text { treatment of patients with } \\
\text { hypertension }\end{array}$ & ** \\
\hline Gordon et al $l^{7}$ & UK & $\begin{array}{l}\text { Face-to-face } \\
\text { interviews }\end{array}$ & CVD & $\begin{array}{l}\text { Thematic } \\
\text { analysis }\end{array}$ & $\begin{array}{l}98 \text { patients ( } 41 \text { males } \\
\text { and } 57 \text { females) aged } \\
\text { between } 32-89 \text { years }\end{array}$ & $\begin{array}{l}\text { Home interviews of } \\
\text { patients recruited from } \\
\text { five general surgeries } \\
\text { and pharmacy } \\
\text { interviews at four } \\
\text { community pharmacies }\end{array}$ & $\begin{array}{l}\text { To examine } \\
\text { medication-related } \\
\text { problems from the } \\
\text { perspective of patients } \\
\text { with a chronic condition } \\
\text { and to identify how they } \\
\text { may be supported in } \\
\text { managing their } \\
\text { medication }\end{array}$ & $* *$ \\
\hline Grace et $a l^{\beta 4}$ & UK & Focus groups & Type 2 DM & $\begin{array}{l}\text { Thematic } \\
\text { analysis }\end{array}$ & $\begin{array}{l}17 \text { focus groups of adult } \\
\text { diabetic patients }\end{array}$ & $\begin{array}{l}\text { Tower Hamlets, a } \\
\text { socioeconomically } \\
\text { deprived } \\
\text { London borough }\end{array}$ & $\begin{array}{l}\text { To understand lay } \\
\text { beliefs and attitudes, } \\
\text { religious teachings and } \\
\text { professional perceptions } \\
\text { in relation to diabetes } \\
\text { prevention in the } \\
\text { Bangladeshi community }\end{array}$ & *** \\
\hline
\end{tabular}




\begin{tabular}{|c|c|c|c|c|c|c|c|c|}
\hline Study & Country & Study type & $\begin{array}{l}\text { Patients' } \\
\text { diagnosis }\end{array}$ & $\begin{array}{l}\text { Method of } \\
\text { analysis }\end{array}$ & Study population & Study settings & Study aims & $\begin{array}{l}\text { Study } \\
\text { quality }\end{array}$ \\
\hline Heymann et $a \beta^{35}$ & UK & Focus groups & $\begin{array}{l}\text { DM and } \\
\text { HTN }\end{array}$ & $\begin{array}{l}\text { Thematic } \\
\text { analysis }\end{array}$ & $\begin{array}{l}10 \text { focus groups of } 86 \\
\text { patients (42 males and } \\
44 \text { females) with } \\
\text { hypertension in three } \\
\text { age ranges: } 41-50, \\
51-60,61-70 \text { years (six } \\
\text { groups); and patients } \\
\text { with hypertension and } \\
\text { DM in the age ranges: } \\
51-60,61-70 \text { years } \\
\text { (a total of four groups) }\end{array}$ & UK & $\begin{array}{l}\text { To explore beliefs and } \\
\text { perceptions regarding } \\
\text { hypertension and to gain } \\
\text { an understanding of } \\
\text { barriers to treatment } \\
\text { among patients with and } \\
\text { without DM }\end{array}$ & *** \\
\hline Hu et $a^{\beta 9}$ & USA & Focus groups & Type 2 DM & $\begin{array}{l}\text { Content } \\
\text { analysis }\end{array}$ & $\begin{array}{l}\text { Five focus groups of } 73 \\
\text { Hispanic immigrants; } \\
18 \text { years or older }\end{array}$ & $\begin{array}{l}\text { Free health clinic in } \\
\text { central North Carolina }\end{array}$ & $\begin{array}{l}\text { To explore perceived } \\
\text { barriers among Hispanic } \\
\text { immigrants with diabetes } \\
\text { and their family } \\
\text { members }\end{array}$ & ** \\
\hline Jolles et $a P^{4}$ & Canada & $\begin{array}{l}\text { Semistructured } \\
\text { interviews }\end{array}$ & HTN & $\begin{array}{l}\text { Thematic } \\
\text { analysis }\end{array}$ & $\begin{array}{l}26 \text { patients, aged } \\
\text { between } 26-85 \text { years } \\
\text { and } 62 \% \text { females, able } \\
\text { to speak, read and write } \\
\text { English; diagnosed with } \\
\text { hypertension by a } \\
\text { healthcare provider, and } \\
\text { currently taking an } \\
\text { antihypertensive } \\
\text { medication }\end{array}$ & $\begin{array}{l}\text { Two hypertension clinics } \\
\text { at the University of } \\
\text { Alberta in Edmonton }\end{array}$ & $\begin{array}{l}\text { To understand } \\
\text { hypertensive patients' } \\
\text { perspectives regarding } \\
\text { blood pressure and } \\
\text { hypertension treatment }\end{array}$ & $* *$ \\
\hline Kiawi et $a^{P^{3}}$ & Cameroon & $\begin{array}{l}\text { In-depth interviews, } \\
\text { semi-structured }\end{array}$ & $\begin{array}{l}\text { Type } 2 \\
\text { DM, HTN } \\
\text { and stroke }\end{array}$ & $\begin{array}{l}\text { Content } \\
\text { analysis }\end{array}$ & $\begin{array}{l}15 \text { interviews of } 62 \\
\text { patients ( } 27 \text { women and } \\
\text { five men); selection } \\
\text { criteria included: having } \\
\text { lived at least six months } \\
\text { in the community, being } \\
\text { nominated by other } \\
\text { community members, } \\
\text { and aged above } \\
15 \text { years }\end{array}$ & $\begin{array}{l}\text { Four urban health } \\
\text { districts, one from each } \\
\text { of the main ecological } \\
\text { areas of Cameroon }\end{array}$ & $\begin{array}{l}\text { To investigate the lay } \\
\text { knowledge, attitudes and } \\
\text { behaviours relating to } \\
\text { diabetes and its main } \\
\text { risk factors of urban } \\
\text { Cameroonians }\end{array}$ & 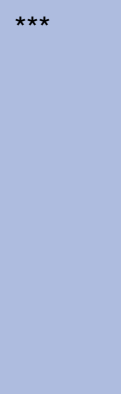 \\
\hline
\end{tabular}




\begin{tabular}{|c|c|c|c|c|c|c|c|c|}
\hline Study & Country & Study type & $\begin{array}{l}\text { Patients' } \\
\text { diagnosis }\end{array}$ & $\begin{array}{l}\text { Method of } \\
\text { analysis }\end{array}$ & Study population & Study settings & Study aims & $\begin{array}{l}\text { Study } \\
\text { quality }\end{array}$ \\
\hline Lai et $a \beta^{\beta 1}$ & Taiwan & In-depth interviews & Type 2 DM & $\begin{array}{l}\text { Thematic } \\
\text { analysis }\end{array}$ & $\begin{array}{l}22 \text { diabetic patients } \\
\text { ( } 12 \text { males and } 10 \\
\text { females), aged between } \\
44-80 \text { years, with a } \\
\text { duration of illness more } \\
\text { than } 1 \text { year }\end{array}$ & Rural Taiwan community & $\begin{array}{l}\text { To investigate Chinese } \\
\text { diabetic patients' } \\
\text { perceptions about their } \\
\text { illness and treatment } \\
\text { strategies to facilitate } \\
\text { patient-centred, } \\
\text { culture-sensitive clinical } \\
\text { skills }\end{array}$ & ** \\
\hline Lawton et $a \beta^{\beta 6}$ & UK & $\begin{array}{l}\text { In-depth interviews } \\
\text { with open-ended } \\
\text { approach }\end{array}$ & Type 2 DM & $\begin{array}{l}\text { Thematic } \\
\text { analysis }\end{array}$ & $\begin{array}{l}31 \text { patients ( } 23 \text { Pakistani } \\
\text { and eight Indian), aged } \\
18 \text { years and over, and } \\
\text { diagnosed with type } 2 \\
\text { DM }\end{array}$ & $\begin{array}{l}\text { General practices in } \\
\text { Edinburgh }\end{array}$ & $\begin{array}{l}\text { Patients' perception and } \\
\text { practical considerations }\end{array}$ & ** \\
\hline $\begin{array}{l}\text { Mohd Ali and Jussoff } \\
2009^{28}\end{array}$ & Malaysia & $\begin{array}{l}\text { In-depth } \\
\text { open-ended } \\
\text { interviews }\end{array}$ & Type 2 DM & $\begin{array}{l}\text { Thematic } \\
\text { analysis }\end{array}$ & $\begin{array}{l}18 \text { patients ( } 9 \text { males and } \\
9 \text { females) aged } \\
\text { between } 15-75 \text { years } \\
\text { and } 13 \text { healthcare } \\
\text { professionals ( } 9 \text { doctors, } \\
\text { three pharmacists and } \\
\text { one diabetic nurse } \\
\text { educator) }\end{array}$ & $\begin{array}{l}\text { Endocrinology clinic of a } \\
\text { teaching hospital in } \\
\text { Kuala Lumpur }\end{array}$ & $\begin{array}{l}\text { To explore the } \\
\text { perspectives and } \\
\text { experiences of Malay } \\
\text { patients in managing } \\
\text { type } 2 \text { DM as a chronic } \\
\text { illness and to provide } \\
\text { recommendations that } \\
\text { aim to enhance } \\
\text { adherence to treatment } \\
\text { and help patients to } \\
\text { improve their } \\
\text { self-management skills }\end{array}$ & $* * *$ \\
\hline Mshunqane et $a^{29}$ & $\begin{array}{l}\text { South } \\
\text { Africa }\end{array}$ & $\begin{array}{l}\text { Patient focus } \\
\text { groups }(n=10) \text { and } \\
\text { healthcare } \\
\text { professional focus } \\
\text { groups }(n=8) \text { and } \\
\text { in-depth interviews. } \\
\text { The questions were } \\
\text { open-ended }\end{array}$ & Type 2 DM & $\begin{array}{l}\text { Thematic } \\
\text { analysis }\end{array}$ & $\begin{array}{l}\text { Patients who had been } \\
\text { diagnosed with type } 2 \\
\text { diabetes for at least } \\
1 \text { year, and were aged } \\
\text { between } 30 \text { and } 65 \text { years }\end{array}$ & $\begin{array}{l}\text { Dr George Mukhari } \\
\text { Hospital outpatients' } \\
\text { diabetes clinic }\end{array}$ & $\begin{array}{l}\text { To determine the } \\
\text { knowledge that patients } \\
\text { with type } 2 \text { DM have } \\
\text { about the management } \\
\text { of their disease, as well } \\
\text { as the perceptions of the } \\
\text { healthcare team about } \\
\text { the services given to } \\
\text { patients }\end{array}$ & $* \star *$ \\
\hline Peel et $a \beta^{\beta 7}$ & UK & In-depth interviews & Type 2 DM & $\begin{array}{l}\text { Thematic } \\
\text { analysis }\end{array}$ & $\begin{array}{l}40 \text { newly diagnosed type } \\
2 \text { DM patients aged } \\
\text { between } 21-77 \text { years }\end{array}$ & $\begin{array}{l}\text { Across the Lothian } \\
\text { region in Scotland }\end{array}$ & $\begin{array}{l}\text { To explore the patients' } \\
\text { emotional reactions } \\
\text { about their type } 2 \text { DM } \\
\text { diagnosis, and their } \\
\text { views about information } \\
\text { provision at the time of } \\
\text { diagnosis }\end{array}$ & ** \\
\hline
\end{tabular}


Table 1 Continued

\begin{tabular}{|c|c|c|c|c|c|c|c|c|}
\hline Study & Country & Study type & $\begin{array}{l}\text { Patients' } \\
\text { diagnosis }\end{array}$ & $\begin{array}{l}\text { Method of } \\
\text { analysis }\end{array}$ & Study population & Study settings & Study aims & $\begin{array}{l}\text { Study } \\
\text { quality }\end{array}$ \\
\hline Peres et $a P^{2}$ & Brazil & Interviews & Type 2 DM & $\begin{array}{l}\text { Content } \\
\text { analysis }\end{array}$ & $\begin{array}{l}24 \text { diabetic females, } \\
\text { aged between } 25 \text { and } 76 \\
\text { years old, literate, with } \\
\text { eight years of schooling, } \\
\text { from Ribeirão Preto, who } \\
\text { perform household } \\
\text { activities }\end{array}$ & $\begin{array}{l}\text { Nursing Education } \\
\text { Center for Adults and } \\
\text { Elderly-CEEAl, } \\
\text { University of São Paulo }\end{array}$ & $\begin{array}{l}\text { Identify the difficulties } \\
\text { patients encounter when } \\
\text { controlling diabetes }\end{array}$ & ** \\
\hline Rustveld et $a{ }^{40}$ & USA & Focus groups & Type 2 DM & $\begin{array}{l}\text { Thematic } \\
\text { analysis }\end{array}$ & $\begin{array}{l}34 \text { patients in six focus } \\
\text { groups (three in English } \\
\text { and three in Spanish), } \\
\text { older than } 18 \text { years and } \\
\text { with type } 2 \text { DM }\end{array}$ & $\begin{array}{l}\text { Three HCHD community } \\
\text { health centres in } \\
\text { Houston, Texas, USA }\end{array}$ & $\begin{array}{l}\text { To elicit attitudes, } \\
\text { attributions and } \\
\text { self-efficacy related to } \\
\text { diabetes self-care in } \\
\text { English- as well as } \\
\text { Spanish-speaking } \\
\text { Hispanic men }\end{array}$ & ** \\
\hline Smith et $a^{26}$ & Ireland & Focus groups & Type 2 DM & $\begin{array}{l}\text { Thematic } \\
\text { analysis }\end{array}$ & $\begin{array}{l}25 \text { patients from three } \\
\text { general practices, having } \\
\text { DM for at least } 1 \text { year }\end{array}$ & $\begin{array}{l}\text { Patients were invited to } \\
\text { participate in the focus } \\
\text { group }\end{array}$ & $\begin{array}{l}\text { To explore the views and } \\
\text { health beliefs of patients } \\
\text { with type } 2 \text { DM who had } \\
\text { experienced a new } \\
\text { structured diabetes } \\
\text { shared care service }\end{array}$ & ** \\
\hline Vinter-Repalust et $a^{25}$ & Croatia & Focus groups & Type 2 DM & $\begin{array}{l}\text { Thematic } \\
\text { analysis }\end{array}$ & $\begin{array}{l}\text { Seven focus groups of } \\
49 \text { patients ( } 22 \text { males } \\
\text { and } 27 \text { females), age } \\
\text { range } 44-83 \text { years, } \\
\text { ambulatory patients with } \\
\text { the diagnosis of type } 2 \\
\text { DM, with differences not } \\
\text { only in age and sex, but } \\
\text { in the method of } \\
\text { treatment of diabetes as } \\
\text { well }\end{array}$ & Zagreb Medical School & $\begin{array}{l}\text { To explore type } 2 \\
\text { diabetic patients' } \\
\text { attitudes, thoughts and } \\
\text { fears connected with } \\
\text { their illness; their } \\
\text { expectations of the } \\
\text { healthcare system; and } \\
\text { the problems they } \\
\text { encountered while } \\
\text { adhering to the } \\
\text { therapeutic regimen }\end{array}$ & 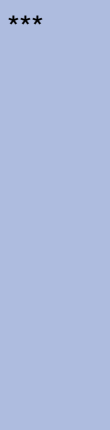 \\
\hline
\end{tabular}

CVD, cardiovascular diseases; DM, diabetes mellitus; HCHD, Harris County Hospital District; HTN, hypertension; USM, Universiti Sains Malaysia.

Studies were grouped into low (one star: 0-3 points), medium (two stars: 4-7 points) and high quality (three stars: 8-10 points). 
Table 2 Themes and subthemes emerging from the studies

Theme/subtheme
Patient-related factors (socioeconomic)
Belief

Family history of condition

Feeling victimised

Lack of finance

Lack of knowledge

Lack of motivation

Lack of information/understanding from doctors

Low self-esteem

Patient-related factors (life-style)

Decrease alcohol intake

Decrease caffeine intake

Diet

Lack of exercise

Lack of time to see doctor

Obesity

Smoking

Stress

\section{Medicine-related factors}

Belief in natural remedies as alternative to medicines

Difficulty/refusal to take medicine

Fear of being stuck with medicines

throughout life

Fear of side effects

Fear of the chemical nature of medicines Forgetfullness

Lack of belief in medicines

Lack of knowledge about medicines' mechanism of actions

Non-adherence

Polypharmacy

Condition related factors

Lack of control over condition

Lack of knowledge/understanding of condition

\section{Countries, studies}

UK (Brown et al, ${ }^{32}$ Grace et al, ${ }^{34}$

Lawton et $a^{\beta 6}$ )

UK (Grace et al, ${ }^{34}$ Lawton et $a^{\beta 6}{ }^{36}$,

USA (Coronado et $a^{\beta 8}$ )

South Africa (Mshunqane et $a^{29}$ ),

Croatia (Vinter-Repalust et $a^{25}$ ), Ireland (Smith et $a^{\text {P6 }}$ )

Ireland (Smith et $a^{{ }^{6}}$ ), South Africa (Mshunqane et $a^{{ }^{9}}$ ), Croatia (Vinter-Repalust et $a^{25}$ ), USA (Hu et $a^{\beta 9}$ )

Croatia (Vinter-Repalust et $a^{25}$ )

Croatia (Vinter-Repalust et $a^{25}$ )

UK (Brown et $a l^{32}$

Choudhury et $a{ }^{33}$ )

Croatia (Vinter-Repalust et $a^{25}$ ),

USA (Rustveld et $a{ }^{40}$ )

Canada (Jolles et $a^{24}$ ),

Canada (Jolles et $a^{R^{4}}$ ),

South Africa (Mshunqane et $a^{{ }^{9}}$ )

Australia (Cotrell et $a^{21}$ ),

Brazil (Peres et $a{ }^{22}$ ), Canada (Jolles et $a^{{ }^{4}}$ ), Croatia (Vinter-Repalust et $a^{{ }^{25}}$ ), Ireland (Smith et $a{ }^{R 6}$ ), UK (Brown et al, ${ }^{32}$ Choudhury et al, ${ }^{33}$ Grace et al, ${ }^{34}$ Heymann et $a l^{35}$ Lawton et $a{ }^{36}$ ), USA (Coronado et $a{ }^{38},{ }^{38} \mathrm{Hu}$ et $a{ }^{39},{ }^{39}$ Rustveld et $a^{40}$ ), South Africa (Mshunqane et $a^{{ }^{29}}$ ), Taiwan (Lai et $a^{\beta 1}$ )

Brazil (Peres et $a f^{22}$ ), Canada (Jolles et $a^{R^{4}}$ ), UK (Brown et al, ${ }^{32}$ Choudhury et $a l,{ }^{33}$ Grace et $a l,{ }^{34}$ Heymann et $a l,{ }^{35}$ Lawton et $a{ }^{36}$ ), South Africa (Mshunqane et $a{ }^{29}$ ), USA (Coronado et al, ${ }^{38} \mathrm{Hu}$ et $a l^{39}$ Rustveld et ${ }^{40}{ }^{40}$ )

Malaysia (Al-Qazaz et $a^{R^{7}}$ )

Brazil (Peres et $a{ }^{22}$ ),

South Africa (Mshunqane et $a^{29}$ ),

UK (Brown et $a{ }^{\beta 2}$ ), USA (Coronado et $a{ }^{\beta 8}$ )

Canada (Jolles et $a^{R^{4}}$ ),

UK (Heymann et $a^{\beta 5}$ )

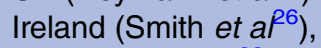

UK (Brown et al, ${ }^{32}$ Grace et $a l^{34}{ }^{34}$ Heymann et $a{ }^{\beta 5}$ ), USA (Coronado et al ${ }^{38}$ )

Spain (Gascon et $a^{\beta 0}$ ),

UK (Brown et $a{ }^{\beta 2}$ ), USA (Coronado et $a^{\beta 8}$ )

Brazil (Peres et $a R^{2}$ ),

Croatia (Vinter-Repalust et $a^{25}$ )

Spain (Gascon et $a^{\beta 0}$ ),

UK (Gordon et $a l^{7}$ )

Ireland (Smith et $a^{{ }^{6}}$ ), Malaysia (Al-Qazaz et $a^{P^{7}}$ ), UK (Heymann et $a^{35}$ ),

Spain (Gascon et $a^{\beta 0}$ ), Taiwan (Lai et $a^{\beta 1}$ )

Taiwan (Lai et $a^{\beta 1}$ ), UK (Brown et $a^{\beta 2}$ )

Brazil (Peres et $a{ }^{22}$ ), Malaysia (Al-Qazaz et al, ${ }^{27}$ Mohd Ali and Jusoff $2009^{28}$ ),

Spain (Gascon et $a^{30}$ )

Australia (Cotrell et $a^{R^{1}}$ )

Canada (Jolles et $a^{R^{4}}$ ),

Spain (Gascon et $a^{\beta 0}$ ), UK (Gordon et $a l^{7}$ )

Canada (Jolles et $a{ }^{24}$ ), Croatia (Vinter-Repalust et $a{ }^{25}$ ), Taiwan (Lai et $a l^{\beta 1}$ ),

UK (Gordon et $a l^{7}$ ), USA ( $\mathrm{Hu}$ et $a l^{39}{ }^{39}$ Rustveld et $a f^{40}$ )

Brazil (Peres et $a{ }^{R 2}$ )

Brazil (Peres et $a^{R^{2}}$ ), Ireland (Smith et $\left.a^{26}\right)$

Australia (Cotrell et $a^{R^{1}}$ ), Cameroon (Kiawi et $a^{23}$ ), Canada (Jolles et $a R^{24}$ ), Malaysia (Al-Qazaz et al, ${ }^{27}$ Mohd Ali and Jusoff $2009^{28}$ ), Spain (Gascon et $a{ }^{\beta 0}$ ), UK (Brown et $a l,{ }^{32}$ Choudhury et $a l,{ }^{33}$ Heymann et $a l,{ }^{35}$ Peele et $a{ }^{37}$ ), USA (Coronado et $a^{\beta 8}$ ) 
Table 2 Continued

\section{Theme/subtheme}

Fear of condition, its causes and complications

Stress from condition

\section{Countries, studies}

South Africa (Mshunqane et $a^{\text {P9 }}$ ),

UK (Choudhury et $a l^{33}$ Lawton et al $2006^{36}$ ), USA (Coronado et $a \beta^{38}$ )

Croatia (Vinter-Repalust et $a^{R 5}$ )

\section{Lifestyle-related factors}

Lifestyle-factors were reported in studies from 11 countries and included: diet (excessive alcohol/caffeine intake), lack of exercise, lack of time to see the doctor, obesity, smoking and stress.

Diet was a major issue stated in 16 studies (table 2). In this respect, patients had different behaviours towards their diet. For instance, one group of patients admitted the importance of a healthy diet, yet could not control their diets. ${ }^{22} 31-33$ Thus, one participant reported ${ }^{22}$ :

Regarding the diet, I try to fight so as not to eat certain foods, but sometimes I can't help myself.

In this respect, patients appreciated the importance of a healthy diet in controlling DM, ${ }^{32}$ yet overestimated its importance to be beyond medicines. ${ }^{31}$ They were also aware that a poor diet, including excess alcohol ${ }^{24}$ and caffeine intake, ${ }^{24} 29$ exacerbated their conditions. Another group of patients misunderstood the concept of a healthy diet. They believed that eating bitter foods could control DM, ${ }^{33}$ or applied portion sizes to their diets. ${ }^{40}$ In the latter case, patients had difficulty eating smaller portions and/or even changing their favourite foods. On other occasions, patients claimed that diet quality was responsible for DM. ${ }^{26}$

In addition, a lack of exercise was reported in 11 studies from five countries, including Brazil, ${ }^{22}$ Canada, ${ }^{24}$ the UK, ${ }^{32-36}$ South Africa ${ }^{29}$ and the USA. ${ }^{38-40}$ A group of patients overestimated the importance of exercise, claiming that it can cure any existing disease. ${ }^{31}$ Patients reported difficulty exercising although they were aware of its importance. ${ }^{36} 40$ They justified their work, travel, stress, the weather and lack of time as the reasons behind their decreased physical exercise. ${ }^{22} 33343639$ A lack of time was more reported in women whose culture expected them to stay indoors after they got married. ${ }^{36}$

Moreover, obesity was described in four studies (Brazil, ${ }^{22}$ South Africa, ${ }^{29}$ the $\mathrm{UK}^{32}$ and the $\mathrm{USA}^{38}$ ) as a cause of DM. Patients blamed weight gain as the cause for their increase in blood glucose level and diabetic complications. ${ }^{32} 38$ Moreover, they attributed insulin to be one of the causes of obesity. ${ }^{32}$

Stress emerged in five studies from three countries, including Ireland, ${ }^{26}$ the $\mathrm{UK}^{32} 3435$ and the USA. ${ }^{38}$ Stress was identified as a result of changes in culture and climate, poor housing and migration of ethnic minorities. ${ }^{38}$ Patients considered stress to be a major cause of their condition. ${ }^{2632} 34353840$ For instance, one patient reported:
In 1998, my mother died, and I was unable to go to the funeral. During these months, I developed diabetes.

Patients also perceived that stress control could be an effective way to cure their condition ${ }^{34}$ since stress led to a poor diet, smoking and a lack of exercise.

\section{Medicine-related factors}

Medicine-related factors were found in 14 studies from 11 countries and included two types of factors: those related to the use of medicines and those related to knowledge about medicines.

Factors related to the use of medicines included medicine non-adherence and polypharmacy. Medicine nonadherence was reported in 10 studies from seven coun-

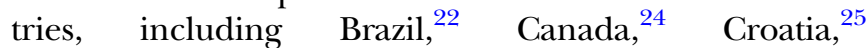
Malaysia, ${ }^{27}{ }^{28}$ Spain, ${ }^{30}$ Taiwan, ${ }^{31}$ the $\mathrm{UK}^{7}$ and the USA. ${ }^{39}$ Patients justified non-adherence to medicines as difficulty following the treatment regimen, ${ }^{25}$ depression and stress, ${ }^{40}$ forgetfulness in taking the medicines, ${ }^{7} 22 \quad 2728 \quad 30$ a lack of routine in taking the medicines, ${ }^{24}$ changes in medicine routines ${ }^{24}$ and the inconvenience of taking insulin. For instance, patients asserted that oral hypoglycaemics are more convenient to take than insulin ${ }^{30}$ :

I prefer pills more than insulin. You know, swallowing a pill causes no pain. And when I know I will eat more I just take another pill or an extra half.

Furthermore, intentional non-adherence was reported in some studies where patients changed their insulin doses depending on their food regimen. ${ }^{30}$ In another scenario, patients stopped taking their medicines when they exercised, acting on the assumption that exercise reduces blood sugar level. Thus, patients changed the dose/regimen of their medicines to fit with their daily activities. $^{7}$

Poylpharmacy was reported among patients with type 2 DM in two studies from Brazil $^{22}$ and Canada. ${ }^{28}$ Polypharmacy caused inconvenience in taking medicines ${ }^{22}$ :

Medication: this has been my biggest problem in this current phase. I take medication for blood pressure, circulation, diabetes, vitamins. I used to mix up the time of each, but today, thanks to orientation, I'm overcoming this stage.

Factors relating to knowledge about medicines included lack of knowledge about how the medicines 
worked, fear of the chemical nature of medicines and their side effects and a lack of belief in medicine.

The lack of knowledge about how medicines worked was described in three studies in Canada, ${ }^{24}$ the $\mathrm{UK}^{7}$ and Spain. ${ }^{30}$ Patients could not identify most of their medicines apart from the diuretics, which they called "water pills. ${ }^{24}$ Moreover, patients could not understand how their medicines worked, even when they read the patient information leaflet. ${ }^{30}$

This lack of knowledge created fear in patients regarding the chemical nature of medicines, the side effects of medicines and being obliged to take medicines all of their lives. ${ }^{7} 2627$ 30-32 35 For instance, patients referred to oral hypoglycaemic agents and insulin as 'pharmaceutical toxins. ${ }^{31}$

Additionally, patients were afraid of the side effects and complications of medicines. They attributed various side effects to medicines, including hypoglycaemia and gastrointestinal disturbances to insulin, ${ }^{32}$ kidney failure to oral hypoglycaemic agents, ${ }^{31}$ and nausea/vomiting to antihypertensive agents. ${ }^{30}$ In the last case, a patient reported:

I don't like them (medicines); they have lots of side effects. They can make you sick... I think that I might get worse instead of better.

These fears promoted a lack of belief in medicines among patients. ${ }^{21}$ Subsequently, patients started to believe in natural remedies as an alternative to medicines. ${ }^{30} 32 \quad 38$ They referred to natural therapies as ' $a$ cure' that should be used alongside traditional medicines. ${ }^{38}$ In another scenario, patients believed that natural therapies were superior to medicines. ${ }^{32}$ In this respect, natural therapies reported for curing DM included natural drinks (composed of minerals and water),$^{38}$ and plant products (such as aloe vera, arnica, cactus, silk cottonwood tree, tree spinach and violet water). ${ }^{32}$

\section{Condition-related factors}

Condition (clinical)-related factors were reported from 11 countries as a major theme. Factors included a lack of knowledge/understanding of the condition, fear of the condition and its complications, stress from the condition and a lack of control over the condition.

Lack of knowledge/understanding of the condition (CVDs/DM) emerged as a major theme in 11 studies from seven countries, including Australia, ${ }^{21}$ Cameroon, ${ }^{23}$ Canada, ${ }^{24}$ Malaysia, ${ }^{27}{ }^{28}$ Spain, ${ }^{30}$ the $\mathrm{UK}^{32} 3335{ }^{37}$ and the $\mathrm{USA}^{38}$

For CVDs, patients expressed a lack of knowledge about their heart failure, HTN and stroke. Patients with heart failure did not know enough about their disease symptoms. ${ }^{21}$ Moreover, hypertensive patients did not understand the nature of their disease, ${ }^{28}{ }^{30}$ struggled to define their condition ${ }^{24}$ and considered it an underlying risk factor to myocardial infarction rather than a disease. ${ }^{35}$ Patients justified their lack of knowledge by citing short consultations with physicians, not obtaining enough information from physicians and obtaining information from non-medical sources such as television and magazines. For instance, one patient reported:

Anything I know about blood pressure I've read in books, the doctor tells me absolutely nothing ... High blood pressure: factors related to compliance with treatment 127. I want him to tell me where high blood pressure comes from.

Similarly, patients with DM lacked knowledge about the disease and misunderstood its causes and complications. ${ }^{23} 252729323336$ Regarding the DM condition and causes, patients' perceptions of DM were influenced by other people's accounts and experiences. ${ }^{32}$ Patients viewed the condition as an illness that took away their health and strength, ${ }^{36}$ changing their lifestyle. ${ }^{25}$ They could not differentiate between types 1 and $2 \mathrm{DM},{ }^{27}$ considered high sugar intake to be the cause of DM, and perceived DM to be sexually and genetically transmitted. ${ }^{23}{ }^{33}$ Moreover, patients believed that diabetes was not dangerous if it did not require insulin. ${ }^{32}$ Patients were only aware of the microvascular complications (such as foot disease) of $\mathrm{DM}^{26}{ }^{26}$ Moreover, they were aware of the disease's signs and symptoms (such as dry mouth, tiredness, dizziness, irritation, blurred vision, micturition and extreme thirst) only after they encountered them. ${ }^{28} 38$

The lack of knowledge about the condition created fear in patients' minds of the disease itself ${ }^{38}$ and they could not accept the disease easily. ${ }^{25} 33$ One patient reported $^{38}$ :

Diabetes is a disease that kills you little by little.

Diseases additionally resulted in stress about the condition, which was particularly observed in patients with multiple comorbidities. ${ }^{36}$ For instance, diabetic patients who had asthma as a comorbidity could not exercise due to asthma symptoms, such as shortness of breath and swollen feet and joints:

They tell you to exercise ... but I can't move around a lot because I have a problem with my leg (arthritis). If I walk a little, then it swells up.

As a result, patients were not able to control their condition, ${ }^{22}{ }^{26}$ which led to frustration, depression and anxiety.

\section{DISCUSSION}

To the best of our knowledge, this review is the first systematic analysis of the perspectives of adult patients with CVDs/DM on contributory factors leading to MRPs. We explored patients' knowledge, beliefs and behaviours towards medicines. The majority of studies evaluated patients with DM; only a few studies evaluated patients 
with CVDs. The three themes emerging from this review included: patient-related (socioeconomic-related and lifestyle-related), clinical-related and medicine-related factors.

\section{Patient-related factors}

\section{Socioeconomic-related factors}

Socioeconomic factors (genetic, cultural behaviour and financial situations) affected patients' perceptions of disease and the medicines contributing to MRPs. Patients perceived genetic factors and religious beliefs to be the cause of their DM. ${ }^{19}{ }^{21}$ Patients from Christian and Muslim backgrounds named God as the cause for their DM. These attitudes were confirmed by other studies which showed that religious values contributed to MRPs. ${ }^{41}{ }^{42}$ In addition, patients felt socially stigmatised by their DM, which affected their self-esteem. They also blamed their financial situation for contributing to MRPs, since their finances prevented them from having the right diet and being able to afford doctors' visits. The cost of therapy has been perceived as being important, particularly with chronic conditions such as CVDs. ${ }^{43}$ Thus, the value that patients receive from healthcare professionals for their money was unsatisfactory. In fact, doctors' attitudes towards the patients played an important role in patients being compliant with their regimens. ${ }^{44}$ This problem was significant in ethnic minorities where a lack of communication between doctors and patients lead to misunderstanding. ${ }^{41}$ Patients confirmed the need for further information and training, emphasising the importance of getting information from healthcare professionals.

\section{Lifestyle-related factors}

Lifestyle factors were perceived as a vital component for the control of conditions (CVDs/DM). Patients felt that they needed to adjust their diet, engage in physical activity and manage their moods to cope with conditions. In relation to diet, they either did not understand the concept of a healthy diet or they had difficulty managing a good diet. Thus, some patients assumed that a healthy diet meant eating less food, eating 'bitter food' or eating 'natural food.' Other patients overestimated the importance of diet as being more crucial than medicines. This overestimation can be attributed to the fact that the frequency of meals could serve as a reminder to take medicines. ${ }^{43}$ In addition, patients were aware of the necessity of physical exercise but blamed the weather, work, lack of time and stress for their not exercising. ${ }^{43}$ Stress was a major factor that patients blamed for not taking medicines on time and for eating a poor diet.

\section{Medicine-related factors}

Medicines were recognised by patients as a contributing factor to MRPs with regard to lack of knowledge about medicines, lack of belief that medicines are good, difficulty taking medicines on time and fear of side effects. Patients reported a lack of knowledge about how the medicines worked, called them pharmaceutical toxins and preferred herbal remedies to medicines. This point was emphasised in another study ${ }^{41}$ that stated that patients' lack of awareness about the use of their medicines led to MRPs. Furthermore, patients reported skipping medicine doses due to forgetfulness or they did not take their medicines on purpose (at the time of exercise). Forgetfulness in terms of taking medicines was observed more often in patients who did not have regular meals. ${ }^{43}$ At other times, patients were scared of the side effects and complications of medicines. The medicines' side effects caused physical discomfort for patients, who started to doubt the therapy's effectiveness and skipped their medicines. ${ }^{43}$

\section{Condition-related factors}

Condition (clinical) factors reported by patients revealed a lack of knowledge about the disease and its cause, a lack of control over the disease and the existence of comorbidities with the disease. ${ }^{43}$ Patients were accordingly not fully aware of their condition and perceived it in most cases as being a risk factor leading to other diseases. Moreover, they misidentified the causes and complications of their condition. Once the education about the condition was provided, patients felt scared and frustrated, which induced a lack of control over the disease. Moreover, the existence of comorbidities with the main condition worsened the patients' adherence to treatment and advice.

\section{Strengths and weaknesses of the review}

This review proposes a systematic and comprehensive approach to qualitative studies of contributory factors to MRPs of adult patients with CVDs/DM. We adopted a thematic synthesis approach to eligible studies regarding the treatment experiences from patients' perspectives. The studies involved 836 participants. However, despite the diversity of the participants and different contexts in the studies, we were able to develop themes that indicated an overlap among the studies.

We used recognised methods from the literature regarding patients' experiences/perspectives in order to synthesise and develop analytical themes. ${ }^{18}{ }^{45} \mathrm{We}$ included the details of each study in relation to the aims, participants, settings and methods applied. We rated the studies' qualities based on methods from the literature. In this respect, we found that studies with the highest ratings contributed most to the final analytical themes.

One limitation of the review is that it was restricted to the experiences of those patients involved in the studies. Moreover, perspectives and beliefs of non-English speaking patients and those seeking palliative care were not integrated into this review due to lack of studies representing them. Thus, the review was extracted from studies in 12 countries only. Therefore, the generalisability of the findings of this review to patients from different countries (other than the 12 aforementioned 
countries) may be difficult. However, the analytical themes developed offer a high level of conceptual thinking that can be applied across different contexts.

\section{Implications of the research}

This review examined the contribution of patients' perceptions, behaviours and beliefs in understanding different aspects of underlying risk factors that may lead to MRPs. Syntheses of the qualitative research on such risk factors should complement the findings from quantitative research. Having a systematic review when planning new qualitative research may help to avoid unintentional examination of questions that have already been extensively researched. Finally, the findings of this study on patients' perspectives could better inform the development of future screening tools and interventions for avoiding MRPs. Additionally, our results may also increase researchers' knowledge of generic issues in this field, even when attempting to target a specific ethnic or cultural group.

\section{Implication towards practices}

Patients' perspectives about medicine use and factors affecting their treatment regimen are often different from the medical viewpoint. Worldwide, people with CVD and/or DM widely perceive that their conditions are principally stress-related conditions and fear addiction or dependence on medicines, which leads to nonadherence to required treatments. These misconceptions and fears commonly cause people to reduce or stop treatment. If we are to be successful at minimising and preventing MRPs, incorporating patients' perspectives as well as considering medical records are of paramount concern. An increased understanding between doctors and their patients must play a part in future strategies for reducing MRPs in patients with CVDs and/ or DM.

\section{CONCLUSIONS}

This thematic synthesis of qualitative studies on patients' perspectives of the potential risk factors of MRPs shows that underlying factors that may lead to MRPs require further in-depth research. Factors influencing patients' success in treatment included patient-related (socioeconomic and lifestyle), medicine-related (fear of medicine, non-adherence and polypharmacy) and conditionrelated factors (fear of condition and its complications). In summary, more qualitative research should be conducted on patients with CVDs and/or DM to understand and address issues related to the treatment regimens and to subsequently reduce the cost of undesired hospital admissions resulting from MRPs.

Contributors AAH participated in protocol development, literature searching, data extraction, data analysis and manuscript preparation. MG participated in protocol development, data analysis, literature searching, data extraction and manuscript preparation. HA participated in protocol development, data analysis and manuscript preparation. ZA participated in protocol development, literature searching, data extraction and manuscript preparation. All authors have read and approved the final manuscript.

Funding This research received no specific grant from any funding agency in the public, commercial or not-for-profit sectors.

Competing interests None.

Provenance and peer review Not commissioned; externally peer reviewed.

Data sharing statement No additional data are available.

Open Access This is an Open Access article distributed in accordance with the Creative Commons Attribution Non Commercial (CC BY-NC 4.0) license, which permits others to distribute, remix, adapt, build upon this work noncommercially, and license their derivative works on different terms, provided the original work is properly cited and the use is non-commercial. See: http:// creativecommons.org/licenses/by-nc/4.0/

\section{REFERENCES}

1. Fernandez-llimos F, Faus M, Gastelurrutia M, et al. Evolution of the concept of drug-related problems: outcomes as the focus of the new paradigm Evolución del concepto de problemas relacionados con medicamentos: resultados como el centro del nuevo paradigma. Seguimieto Farmacoterapeutico 2005;3:167-88.

2. Rozich J, Resar R. Medication safety: one organisation' s approach. J Clin Outcomes Manage 2001;8:27-34.

3. Ruths S, Viktil K, Blix H. [Classification of drug-related problems]. Tidsskr Nor Laegeforen 2007;127:3073-6.

4. Wester K, Jönsson A, Spigset $O$, et al. Incidence of fatal adverse drug reactions: a population based study. $\mathrm{Br} J$ Clin Pharmacol 2008;65:573-9.

5. State of the Nation. 2012 ed. UK: Diabetes UK, 2012.

6. Organisation $\mathrm{WH}$. New data highlight increases in hypertension, diabetes incidence, 2012.

7. Gordon K, Smith F, Dhillon S. Effective chronic disease management: patients' perspectives on medication-related problems. Patient Educ Couns 2007;65:407-15.

8. Schainberg A, Ribeiro-Oliveira A, Ribeiro J. Is there a link between glucose levels and heart failure? An update. Arq Bras Endocrinol Metab 2004;54:488-97.

9. Milicevic Z, Raz I, Beattie S, et al. Natural history of cardiovascular disease in patients with diabetes role of hyperglycemia. Diabetes Care 2008;31(S2):S155-60.

10. Brenson R, Britten N. Patients' decisions about whether or not to take antihypertensive drugs: qualitative study. BMJ 2002;325:873-7.

11. Daly J, Denaro C, Emmerton L. Exploring beliefs about heart failure treatment in adherent and nonadherent patients: use of the repertory grid technique. Patient Prefer Adherence 2013;7:141-50.

12. Huri $\mathrm{H}$, Wee $\mathrm{H}$. Drug related problems in type 2 diabetes patients with hypertension: a cross-sectional retrospective study. BMC Endocr Disord 2013;13:2-14

13. Zaman Huri H, Chai Ling L. Drug-related problems in type 2 diabetes mellitus patients with Dyslipidemia. BMC Public Health 2013;13:1192.

14. Claydon-Platt K, Manias E, Dunning T. Medication-related problems occurring in people with diabetes during an admission to an adult teaching hospital: a retrospective cohort study. Diabetes Res Clin Pract 2012;97:223-30.

15. Haugbolle LS, Sorensen EW. Drug-related problems in patients with angina pectoris, type 2 diabetes and asthma-interviewing patients at home. Pharm World Sci 2006;28:239-47.

16. Al Hamid $A$, Ghaleb $M$, Aljadhey $H$, et al. A systematic review of hospitalisation resulting from medicine related problems in adult patients. Br J Clin Pharmacol 2014;78:202-17.

17. Dixon-Woods M, Bonas S, Booth A, et al. How can systematic reviews incorporate qualitative research? A critical perspective. Qual Res 2006;6:27-34.

18. Lucas $\mathrm{P}$, Baird J, Arai L, et al. Worked examples of alternative methods for the synthesis of qualitative and quantitative research in systematic reviews. BMC Med Res Methodol 2007;7:4.

19. Kruper A, Lingard L, Levinson W. Critically appraising qualitative research. BMJ 2008;337:a1035.

20. Programme CAS. 10 questions to help you make sense of qualitative research. 2013. http://media.wix.com/ugd/dded87 951541699e9edc71ce66c9bac4734c69.pdf (accessed 24 May 2014) 
21. Cottrell WN, Denaro CP, Emmerton L. Exploring beliefs about heart failure treatment in adherent and nonadherent patients: use of the repertory grid technique. Patient Prefer Adherence 2013;7:141-50.

22. Péres $D$, dos Santos $M$, Zanetti M, et al. Difficulties of diabetic patients in the illness control: feelings and behaviors. Rev Latino-am Enfermagem 2007;15:1105-12.

23. Kiawi E, Edwards R, Shu J, et al. Knowledge, attitudes, and behavior relating to diabetes and its main risk factors among urban residents in Cameroon: a qualitative survey. Ethn Dis 2006;16:503-9.

24. Jolles EP, Padwal RS, Clark AM, et al. A qualitative study of patient perspectives about hypertension. ISRN Hypertension 2013;2013:1-10.

25. Vinter-Repalust N, Petrieèek G, Katiæ M. Obstacles which patients with type 2 diabetes meet while adhering to the therapeutic regimen in everyday life: qualitative study. Croat Med $J$ 2004;45:630-6.

26. Smith S, O'Leary M, Bury $\mathrm{G}$, et al. qualitative investigation of the views and health beliefs of patients with type 2 diabetes following the introduction of a diabetes shared care service. Diabet Med 2003;20:853-7.

27. Al-Qazaz HK, Hassali MA, Shafie AA, et al. Perception and knowledge of patients with type 2 diabetes in Malaysia about their disease and medication: a qualitative study. RSAP 2011;7:180-91.

28. Mohd Ali $S$, Jusoff $D$. Barriers to optimal control of type 2 diabetes in Malaysian Malay patients. Global J Health Sci 2009;1:106-18.

29. Mshunqane N, Stewart AV, Rothberg AD. Type 2 diabetes management: patient knowledge and health care team perceptions, South Africa. Afr J Prim Health Care Fam Med 2012;4:392-8.

30. Gascón J, Sánchez-Ortuño M, Llor B, et al. Why hypertensive patients do not comply with the treatment. Fam Pract 2004;21:125-30.

31. Lai WA, Lew-Ting CY, Chie WC. How diabetic patients think about and manage their illness in Taiwan. Diabet Med 2005;22:286-92.

32. Brown KA, Avis M, Hubbard M. Health beliefs of African-Caribbean people with type 2 diabetes: a qualitative study. $\mathrm{Br} J$ Clin Pract 2007:57:461-70.
33. Choudhury SM, Brophy S, Williams R. Understanding and beliefs of diabetes in the UK Bangladeshi population. Diabet Med 2009;26:636-40.

34. Grace C, Begum R, Subhani S, et al. Prevention of type 2 diabetes in British Bangladeshis: qualitative study of community, religious, and professional perspectives. BMJ 2008;337:a1931.

35. Heymann A, Valinsky L, Inbar Z, et al. Perceptions of hypertension treatment among patients with and without diabetes. BMC Fam Pract 2012;13:24-30.

36. Lawton J, Ahmad N, Hanna L, et al. 'I can't do any serious exercise' barriers to physical activity amongst people of Pakistani and Indian origin with type 2 diabetes. Health Educ Res 2006;21:43-54.

37. Peel E, Parry O, Douglas M, et al. Diagnosis of type 2 diabetes: a qualitative analysis of patients' emotional reactions and views about information provision. Patient Educ Couns 2004;53:269-75.

38. Coronado G, Thompson B, Tejeda S, et al. Attitudes and beliefs among Mexican Americans about type 2 diabetes. $J$ Health Care Poor Underserved 2004;15:576-88.

39. Hu J, Amirehsani K, Wallace DC, et al. Perceptions of barriers in managing diabetes: perspectives of Hispanic immigrant patients and family members. Diabetes Educ 2013;39:494-503.

40. Rustveld L, Pavlik V, Jibaja-Weiss M, et al. Adherence to diabetes self-care behaviors in english- and spanish-speaking hispanic men. Patient Preference Adherence 2009;3:123-30.

41. Alhomoud F, Dhillon S, Aslanpour Z, et al. Medicine use and medicine-related problems experienced by ethnic minority patients in the United Kingdom: a review. Int J Pharm Pract 2013;21:277-8.

42. Peeters E, Parry O, Douglas M, et al. Diagnosis of type 2 diabetes: a qualitative analysis of patients' emotional reactions and views about information provision. Patient Educ Couns 2004;53:269-75.

43. Jin J, Sklar G, Oh V, et al. Factors affecting therapeutic compliance: a review from the patient's perspective. Ther Clin Risk Manage 2008:4:269-76

44. Vermeire E, Hearnshaw $\mathrm{H}$, Van Royan $\mathrm{P}$, et al. Patient adherence to treatment: three decades of research. A comprehensive review. J Clin Pharm Ther 2001;26:331-42.

45. Thomas J, Harden A. Methods for the thematic synthesis of qualitative research in systematic reviews. BMC Med Res Methodol 2008;8:45-52. 